\title{
FONT AND COLOUR ATTRIBUTES AS MANIPULATED IN MASS MEDIA TEXTS: PSYCHOLINGUISTIC IMPLICATIONS
}

\author{
Larysa Makaruk \\ https://orcid.org/0000-0002-8988-2753 \\ laryssa makaruk@vnu.edu.ua \\ Lesya Ukrainka Volyn National University, Ukraine
}

Received June 3, 2020; Revised August 8, 2020; Accepted September 4, 2020

\begin{abstract}
In this paper an analysis is presented of font and colour as non-verbal and paralingual components which have the capacity to influence and manipulate recipients of a message. On the basis of an extensive body of illustrative material, it has been established that by the use of colour variation, a single text fragment may be interpreted in several different ways, and may also be perceived differently by men and by women. It is demonstrated that colour and font characteristics are not exclusively graphic shells whose function is merely to record an oral statement in writing. They are semantically significant and multifunctional. It has been determined that font and colour are form-creating elements, which make possible the graphic reproduction of objects in everyday use, objects relating to reality and actuality. Variation in font and colour enable us to hypothesize that the mass media communication space is now characterized by a type of linguistic play utilizing these traits so as to render possible the projection of multiple-reading promotional texts. They also permit an economy in terms of space because of the fact that font techniques can perform formative and content functions simultaneously. Based on an experiment involving 60 participants, 30 of whom were male and 30 female, it was found that the information encoded in colour and font graphics shells is not difficult to perceive and to decipher. However, the survey found that women are more likely to perceive that information, although the difference in perception is not striking. When asked whether a sample of illustrative material stirred an appetite by using stylized fonts consisting of foods to convey a food-related message, $74 \%$ of men and $37 \%$ of women in both samples answered in the positive, which in our study confirms the claim that food advertising promotes appetite arousal. The study also showed that most women who read the information perceive it holistically-their attention is not attracted solely by verbal and nonverbal components. On the other hand, only half of the men surveyed saw it as a whole, and almost a third of them initially noticed the verbal components first. Most participants in the experiment claimed that it took them from 5 to 10 seconds to realize that a single message could be read in several different ways. The participants who took part confirm that a single text string can be interpreted in multiple ways due to the font and colour attributes that are utilized in forming them.
\end{abstract}

Keywords: font, colour, multimodal, verbal, non-verbal, play.

Макарук Лариса. Маніпулятивні ознаки шрифту та кольору в масмедійних текстах та їхні психолінгвістичні характеристики.

Анотація. У роботі проаналізовано шрифт і колір як невербальні та паралінгвальні компоненти, які здатні здійснювати вплив на реципієнта та маніпулювати ним. На основі об'ємного корпусу ілюстративного матеріалу встановлено, що завдяки залученню кольору один і той само текстовий фрагмент може мати кілька варіантів прочитання і по-різному

(C) Makaruk, Larysa, 2020.

This is an Open Access article distributed under the terms and conditions of the Creative Commons Attribution 4.0 International Licence (http://creativecommons.org/licenses/by/4.0).

East European Journal of Psycholinguistics, 7(2), 201-213. https://doi.org/10.29038/eejpl.2020.7.2.mak 
сприймається особами чоловічої та жіночої статей. Доведено, що колір та шрифт не є виключно графічними оболонками, покликання яких - зафіксувати усне висловлювання на письмі. Вони семантично значущі та поліфункційні. Виявлено, що шрифт та колір $є$ формотворчими елементами, завдяки яким графічно відтворюють предмети повсякденного вжитку, об'єкти дійсності, реалії. Варіювання шрифтом та кольором дає підстави стверджувати, що для масмедійного комунікативного простору характерною є лінгвальна гра, яка завдяки шрифту та кольору реалізується у поліваріантному прочитанні рекламного блоку, економії місця, завдяки тому, що шрифт може виконувати формотворчу та змістотворчу функції одночасно. На основі проведеного експерименту, в якому брало участь 60 учасників, 30 з яких особи чоловічої статі і 30 жіночої, встановлено, що закодована у кольорових та шрифтових графічних оболонках інформація не є складною для сприйняття i дешифрування змісту. Однак, опитування виявило, що швидше сприймають таку інформацію жінки, хоча різниця у сприйнятті не $є$ разючою. $74 \%$ учасників чоловічої та $37 \%$ жіночої статей на питання щодо того, чи вибірка ілюстративного матеріалу, яка репрезентує їжу засобами їжі пробуджує апетит, відповіли «так». Це підтверджує припущення, що реклама продуктів харчування сприяє пробудженню апетиту. Дослідження також засвідчило, що більшість жінок, читаючи інформацію, сприймають ії цілісно, тобто їхню увагу не привертають вербальні та невербальні складники поодинці. Натомість лише половина опитаних чоловіків бачать її як одне ціле, й майже третині спершу впадають у око вербальні складники. Більшість учасників експерименту стверджують, що їм достатньо від 5 до 10 секунд, аби зрозуміти, що одне повідомлення можна прочитати кількома способами. Опитувані також підтвердили, що один і то й само фрагмент можна читати по-різному завдяки шрифту та кольору, з яких він створений.

Ключові слова: шрифт, колір, мультимодальний, вербальний, невербальний, гра.

\section{Introduction}

In the modern English-language mass media communicative space, font and colour play a role which is a great deal more important than was the case even a few years ago. Whereas font characteristics used to be a relatively neutral element mainly reflecting relatively superficial esthetic preferences, they now represent an actual resource which can exercise various functions including semantic loading. Since new patterns of font usage open up these semantic and even polysemantic possibilities, the whole process of reading and interpreting texts may be altered.

Modern mass media multimodal advertisements consist of enclaves which combine verbal and non-verbal elements. In many cases verbal ones do not possess as great a manipulative potential as non-verbal and paraverbal components. The most conspicuous of these include the insertion of images, and the manipulation of text (involving colour, and special effects such as variations in font size and weight, and text position) which are essential components of advertisements in both paper and digital periodicals. The usage of verbal and non-verbal elements confirms the fact that now we deal with multimodal texts.

There has been a rapid increase in the number of studies devoted to multimodality in recent decades: among the most prominent scholars who deal with multimodality from varying perspectives are such scholars as Bateman (Bateman, 2014; Bateman 2017), Bergstrom (Bergstrom, 2008), Cleirigh (Cleirigh, 2009), Jewitt (Jewitt, 2014), O’Halloran (O’Halloran, 2014), Hiippala (Hiippala, 2017), 
Kress (Kress, 1996), van Leeuwen (van Leeuwen, 1996), Lester (Lester, 2006), Makaruk (Makaruk, 2018), Mealing (Mealing, 2008), Nørgaard (Nørgaard, 2018), Unsworth (Unsworth, 2009), Wildfeuer (Wildfeuer, 2017). They are involved in various areas of research in terms of styles and genres, as well as in terms of the aspects considered and the research methods applied.

\section{Methods}

The methodological basis of the study of multimodal constructions involves the following methods: the inductive, deductive, descriptive, distributive, systemfunctional, and socio-semiotic methods. The comparative method, the method of visual syntax and the semantic-stylistic method are also used in the work. The technique that was selected made it possible to conduct a comprehensive study of multimodal constructions which constituted a symbiotic fusion of verbal, nonverbal and paraverbal resources. It should be noted to begin with that the method of continuous sampling was used, which made it possible to identify the verbal, nonverbal and paraverbal components to be analyzed. Using induction and deduction, it was possible to identify the semantic and structural features of nonverbal and paraverbal units, their functional load, functioning at the syntactic level. Distributive analysis enabled us to investigate the environment of multimodal graphemes, lexemes and syntactic constructions and to formulate possible methods for combining verbal and nonverbal units. It was found that most of them are interchangeable and can perform a variety of different roles and functions. The socio-semiotic approach involves primarily the processes associated with the expression of meaning in general, and the formulation of meaningful communicative output by individuals in particular; it also focuses on the relationship between modes and their compatibility, and the social needs for which they serve, taking into account the individual producing the sign and the context in which these meanings are realized. The comparative method made it possible to implement comparative steps to identify common and different parameters within the constructs identified in the media. Given the basis of the comparative method and the method of visual syntax, the essence of which is to study multimodal constructs, which are dominated by illustrative components, it became possible to distinguish their components, semantics and most common types based on the proposed criteria. We conducted a survey involving sixty native speakers of English, who filled in an online survey.

In this experiment, which was designed to shed light on the perceiving of multimodal information presented using verbal, paraverbal and non-verbal means, sixty native speakers of English between 20 and 40 years of age, thirty male and thirty female, filled in a survey which contained pictures to be analyzed, with no time limit imposed.

\subsection{Procedure}

As we have already mentioned, in the modern English-language 
communicative space a special role is played by font and colour. This makes possible a dual interpretation of a text, creating a 'play' effect with lingual implications, in linguistic terms. The stylistic basis can take the form of both font and colour, as well as additional elements of a verbal or non-verbal nature. Certain manipulations can be made with the fonts themselves, changing the original purpose of the components, imbuing them with new values that, according to their producers, are most relevant to convey the desired meaning. Figure 1 demonstrates colour variation in the background of a single word, which makes it possible to read either "DON'T DRINK AND DRIVE" or "DON'T DRINK AND DIE". It is obvious that the watchword of the advertisement is that drunken driving causes deaths. In addition, those fatal consequences are implied by the cross-shaped font, suggestive of the cross that is traditionally placed on the tombs of Orthodox Christians. In this way the point is underscored that drunken driving can lead to fatal consequences. As we can see, font features are capable of contributing to the effectiveness of factual elements. In the media communicative space, font and colour as separate modes are often closely interconnected and able to present the content of the message, giving it either positive or negative connotations. We see several colours in this picture, including the dominant black (associated with death) and red (suggestive of blood). This choice of colours is intentional, conveying meaning and coinciding with common-related mental associations.

Figure 1.

Warning against drunk driving

(Pinterest, 2018)

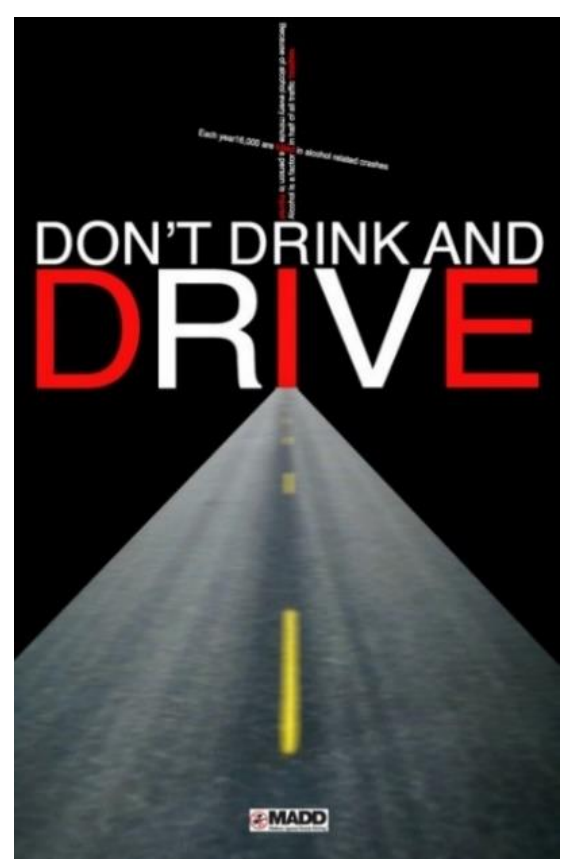

A dual interpretation is also possible in Figure 2, which presents a strong message relating to a potentially fatal disease which can often be successfully treated if the diagnosis is timely: "BREAST CANCER" and "BEAT CANCER". 
The creators of this advertisement are seeking to persuade people to consider what happens to those who are sick and not to forget about the charity that can help those who are ill. Unlike the previous picture, the latter represents the use of additional elements of a non-verbal nature like such as pink ribbons, which are a symbol of breast cancer. In this case, once again, the choice of the colour is not a mere coincidence, but is evidently chosen to represent a generally-accepted concept and to convey meaning through this colour association.

Figure 2.

Early detection of breast cancer (a)

(Blog Anubis, 2017)

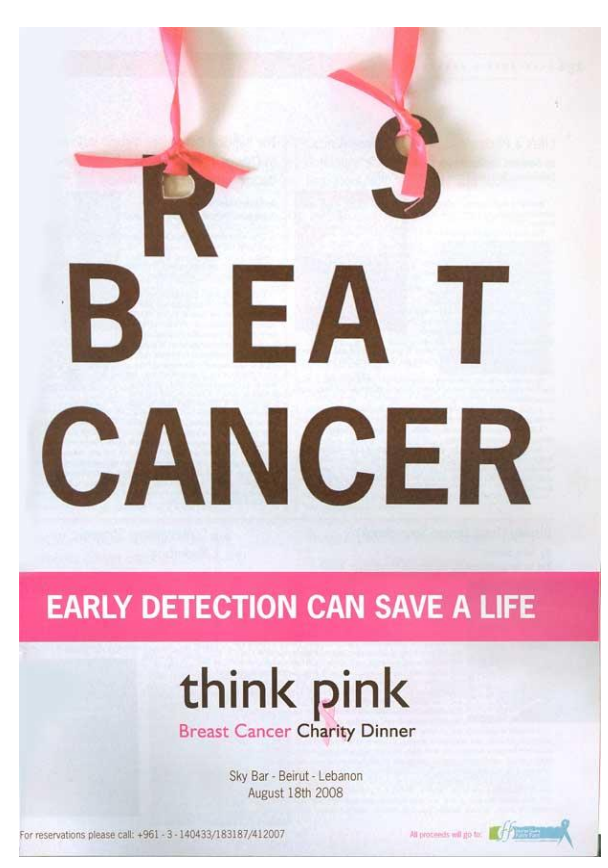

The dual-reading strategy is also a feature of the sentence in Figure 3, which points to the possibility of this illness being conquered if it is diagnosed soon enough. The choice of the eraser is an interesting tactic, because it combines the concept of removing the threat posed by the disease, with the transformation of the message when two key letters are removed. Overcoming the disease would be much easier if examinations and diagnoses were carried out sooner. The use of the eraser is the key to conveying the stylistic meaning. We understand that it is easier to erase a few barely-visible letters (shown by the shadow and the eraser remnants) than to eradicate the disease, which often has fatal consequences. In the example above, we are able to follow the dual-option reading. The explicitly promotional message is presented in dark blue text, but upon more careful observation, the two additional letters ' $R$ ' and ' $S$ ' become identifiable, indicating the specific nature of the disease that is involved. This 'play' with multimodal effects illustrates the potential effectiveness of these manipulations in increasing the persuasiveness of the text which is presented. 
Figure 3.

Early detection of breast cancer (b)

(Senor Snacks, 2017)

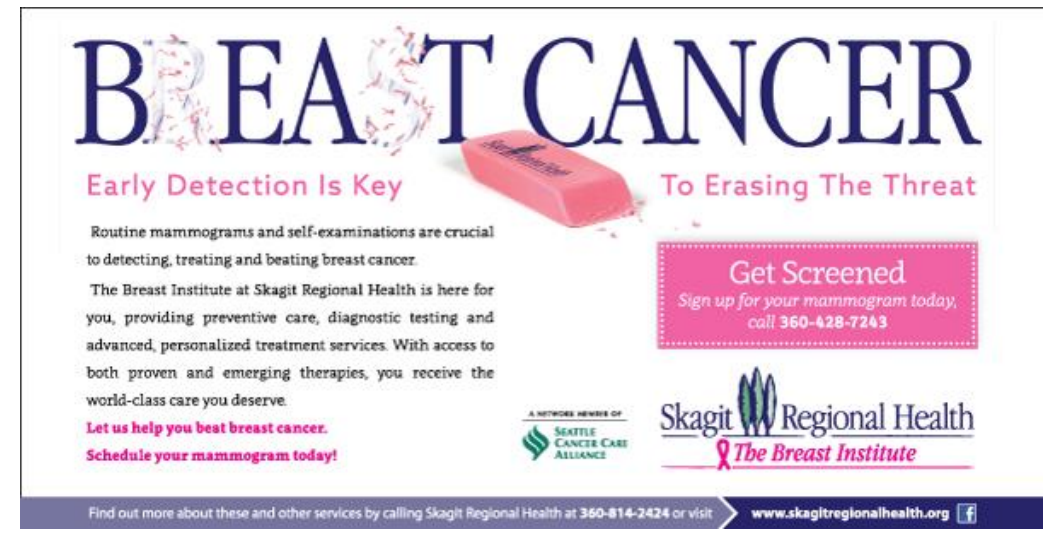

The ominous warning hidden in the billboard message shown in Figure 4 relates to the same potentially fatal disease as the previous two. However, the targeted usage of text colour use makes it possible to read two different sentences: the first one is evidently, "I HAD A CHESTY COUGH THAT WOULDN'T GO AWAY. I GOT CHECKED AFTER THREE WEEKS". The strategy that was chosen by the message's creator was to partially conceal the grim diagnosis conveyed through the alternate reading, leading up to the open warning and recommendation. The implication is clearly that some specific symptoms enable doctors diagnose the disease: "I HAD CANCER". In this example that has been analyzed, colour is an attribute that actually is suggestive of well-being. It is left to the reader to perceive the two sentences which are separate but sequential.

Figure 4.

Prompt checking for lung cancer

(Ireland's, 2018)

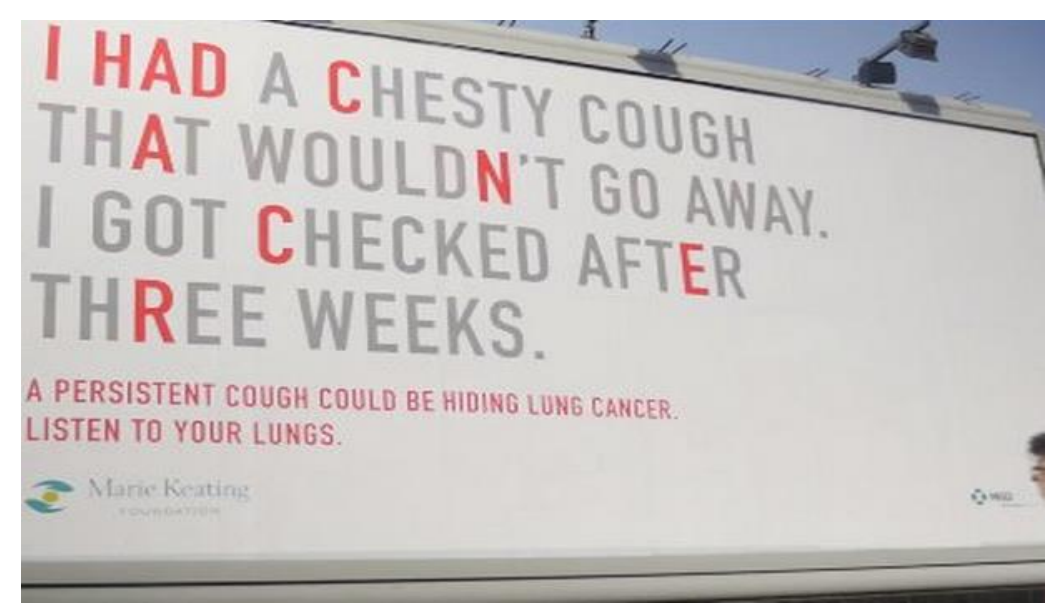

A special dual reading is introduced in Figure 5. This is where the colour play is no longer against the backdrop of lexemes - individual letters - but of entire 
phrases, the combination of which also forms a complete sentence. We observe the simultaneous manipulation of the lines. Drivers are warned not to take the risk of texting on their phones while driving, since during even a five-second distraction a car will travel a distance equal to the length of the football field. The two small hearts suggest that romantic feelings sometimes motivate the dangerous texting. The key message to be conveyed is accentuated by the use of the brighter (orange) contrasting colour for the imperative-mood statement that accompanies the internationally-known stop sign, which in this case has implications beyond what an ordinary stop sign would have: "Drivers off the road while texting".

Figure 5.

Warning not to text while driving

(Pinterest, 2018)

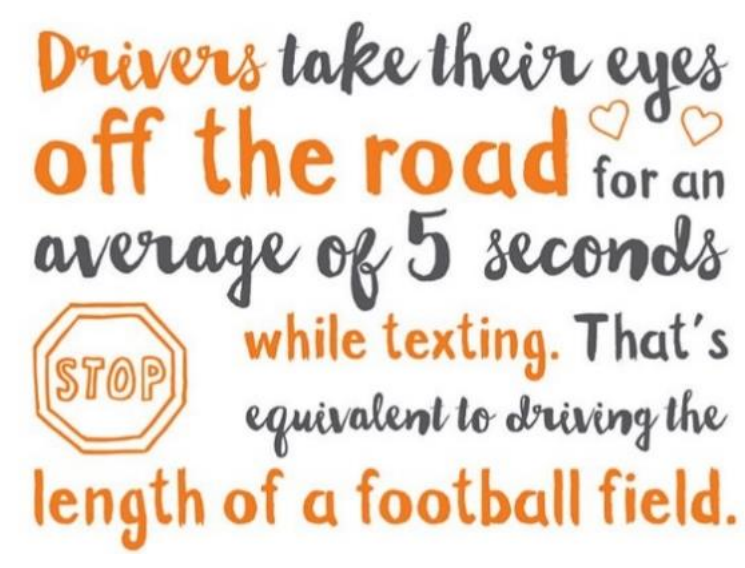

Figure 6 is of interest with respect to the technique used by the writer who crafted the message, which appeared on a cover of the well-known American The New York Times Magazine immediately after the 2016 election. It was evidently intended to convey some ideas connected with the lead article inside the magazine, dealing with the implications of Donald Trump's victory, entitled "Reflections from Trump's America". This title appears in such a tiny typeface that at first glance it seems to just be a decorative feature on either side of the word "IS". The entire large caption was the title of Woody Guthrie's famous song, but the highlighting of the letters forming the words "his" and "our" pointed to the question in many people's minds: is this land his land, or our land? For many shocked observers, their own identity and that of their country was a matter of conjecture. The multimodal technique of using contrasting text colour as an accentuation strategy involved a switching of the semantics of one lexeme to another. It is our conclusion that this font-related technique could be classed as a distinctive kind of 'play', and involves custom-made font patterns that are not available in ordinary software applications. The purpose of this play is to bring the reader as close as possible to objective reality, to show what the advertised product really is, or what the advertised service can offer. 
Figure 6.

New York Times Magazine cover

(Pinterest, 2018)

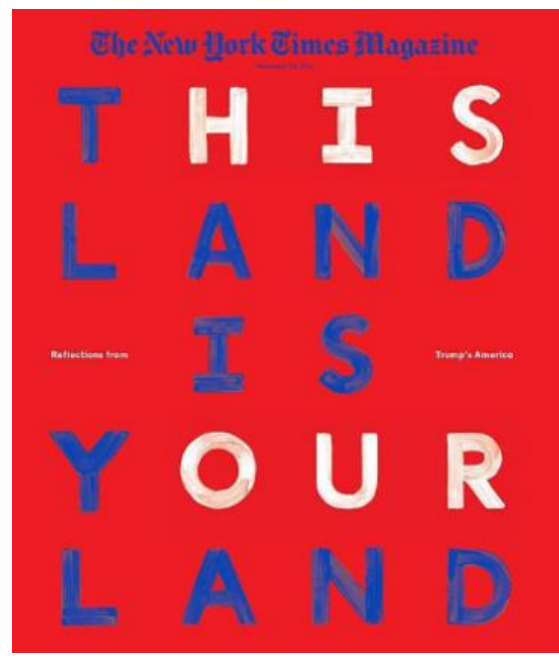

In Figure 7, alphabetical characters are presented in such a way that by virtue of the character positioning and the texture suggestive of specific foods, a nonverbal message combines with the actual letters to form a complex message relating to cheese products. This technique was evidently intended to produce an effect that would appeal to the reader on levels other than the merely visual. In Figure 8 the words "Eat me" are displayed in a font which is composed of physical components suggestive of dishes that are on offer in the dining establishment. This type of presentation is intended to influence readers on a conscious and a subconscious level, with the purpose of attracting them to visit the restaurant themselves.

Figure 5 .

Food imagery composing a font (a)

(Pinterest, 2017)

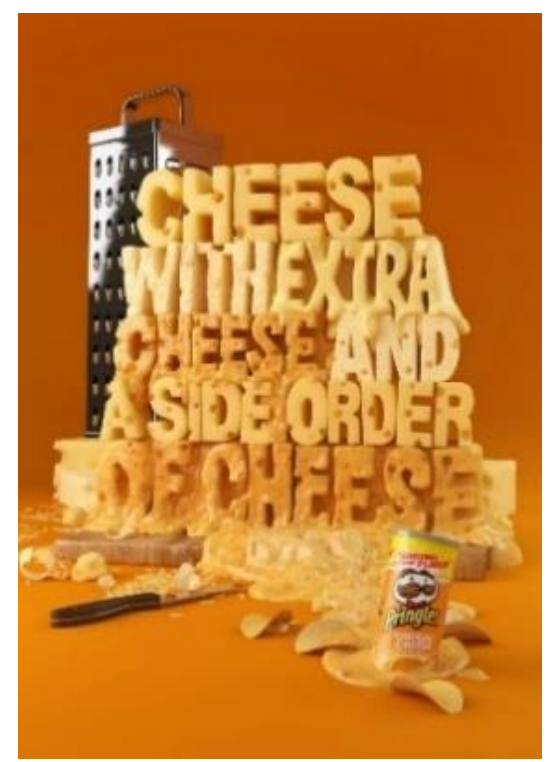


Figure 8.

Food imagery composing a font

(River View Observer, 2016)

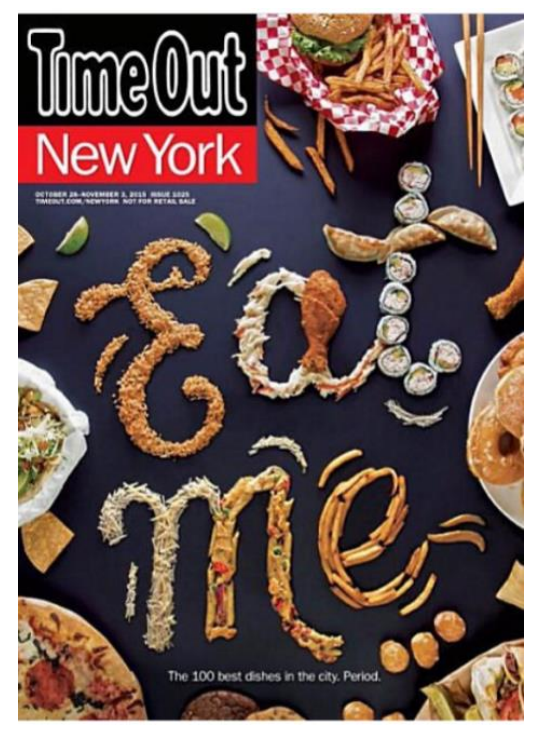

Here we observe the presence of various grapheme objects, the totality of which forms a multimodal sentence. This picture is also related to the play, in particular its varieties - font-like to objects and processes of objective reality with double duplication of semantics.

The last two figures (9 and 10) in this paper present the possibilities of font as a form-creating element. Alphabetical characters are forced into the shape of a bottle and wine glass, in one case, and into the shape of a dessert cup in the other, in a manner which gives a literal representation of these objects while conveying a relevant verbal message at the same time.

Figure 9.

Font manipulation to suggest the form of a pertinent object (a)

(Pinoy Listing, 2018)

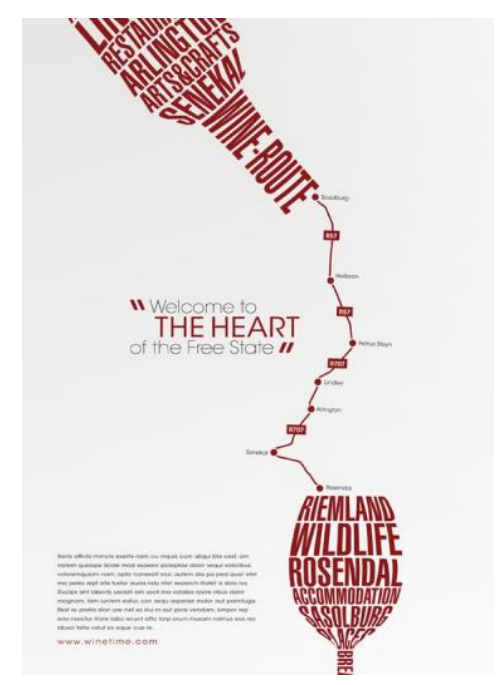


Figure 10.

Font manipulation to suggest the form of a pertinent object $(b)$

(Ads for Rhetorical Analysis, 2017)

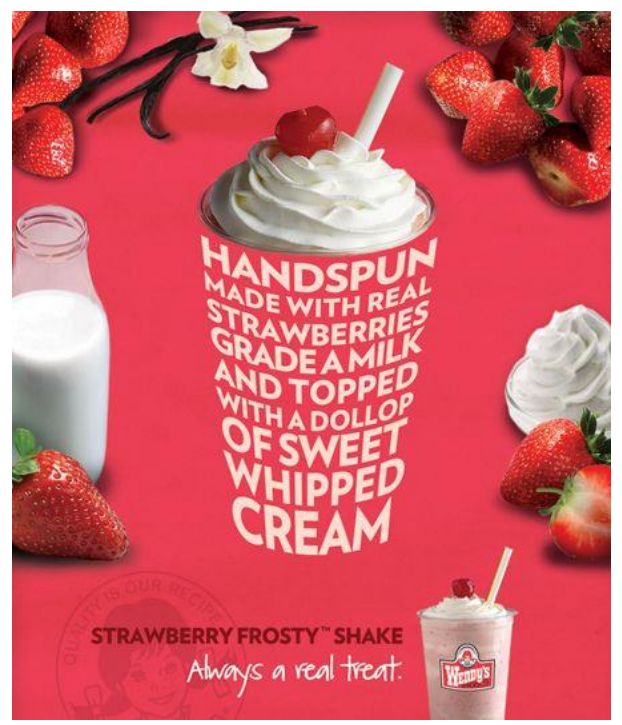

In the first case, the words in the 'deformed' text string tell something about the background of the wine that is being advertised; in the second case, a similar tactic is used to present information about the preparation of the dessert. This illustrates the fact that a 'manipulated font' can be used to create everyday objects. In a sense, this technique alters the semantic content of the message and embodies a duplication of the content.

\section{Results and Discussion}

In order to better understand how people perceive information presented to them through verbal, paraverbal and non-verbal means, we conducted an experiment. For the purpose of studying the process of perceiving, memorizing and recalling images, the survey included five questions shown in the table below, along with the responses which were received (see Table 1).

Table 1.

Survey questions and results derived from the respondents' replies to those questions

Q1 When you see a picture of a multimodal nature (including both verbal and nonverbal (paraverbal) features), is it the verbal aspect which you initially perceive, or the non-verbal aspect? Or do you perceive them together as a single entity?

\begin{tabular}{ll}
\hline Females & Males \\
\hline $13 \%$ verbal & $33 \%$ verbal \\
$17 \%$ non-verbal & $16 \%$ non-verbal \\
$70 \%$ a single entity & $51 \%$ a single entity \\
\hline Q2 How much time did you require to grasp the fact that texts such as those \\
\hline
\end{tabular}


presented in Figures $1-6$ can be read in two different ways?

- 5 seconds? $\bullet 10$ seconds? $\bullet$ more than 10 seconds?

\begin{tabular}{ll}
\hline Females & Males \\
\hline 5 seconds $-63 \%$ & 5 seconds $-50 \%$ \\
10 seconds $-32 \%$ & 10 seconds $-41 \%$ \\
more than 10 seconds $-5 \%$ & more than 10 seconds $-9 \%$
\end{tabular}

Q3 Did you have any difficulty reading the information presented in figures 1-5?

- Yes • No

\begin{tabular}{ll}
\hline Females & Males \\
\hline No $-98 \%$ & No $-92 \%$ \\
Yes $-2 \%$ (Figure 9, because of & Yes $-8 \%$ (Figures 1 and 6, because of the font \\
the small font) & being difficult to decipher) \\
\hline
\end{tabular}

Q4 Do you feel a desire to eat something when you see pictures showing various foods, or texts composed in fonts which actually consist of food imagery?

- Yes • No

\begin{tabular}{ll}
\hline Females & Males \\
\hline Yes $-37 \%$ & Yes $-74 \%$ \\
No $-63 \%$ & No $-26 \%$
\end{tabular}

Q5 When you looked at pictures 9 and 10, how long did it take you to notice the textual content formed by the objects that were presented?

- 10 seconds? $\bullet 15$ seconds? $\bullet$ more than 15 seconds?

\begin{tabular}{ll}
\hline Females & Males \\
\hline 10 seconds $-83 \%$ & 10 seconds $-72 \%$ \\
15 seconds $-17 \%$ & 15 seconds $-20 \%$ \\
more than 15 seconds $-0 \%$ & more than 15 seconds $-8 \%$ \\
\hline
\end{tabular}

When the responses were analysed, it was demonstrated that $70 \%$ of the females who participated in the experiment perceived the information as a single unit, while only $51 \%$ of males did so. $33 \%$ of the males noticed the verbal portion first whereas only $13 \%$ of the females were able to distinguish the verbal information from the whole unit first. With respect to the non-verbal units, the proportions were almost the same. The speed of comprehension by females exceeded that of males by a margin of $10 \%$. On the basis of the responses that were obtained, both males and females were able to comprehend the messages involving font and colour within ten seconds or less, indicating clearly that comprehension was not difficult either for either group. It also demonstrated that advertisements containing food imagery stimulated appetite in twice as many men as women ( $74 \%$, as opposed to $37 \%$ ). The last question was designed to determine whether the readers had any difficulty deciphering the information produced using font and colour in the form of physical objects. The results were almost the same (with a differential of approximately $10 \%$ ) for both sexes, although males were slightly less successful; on the whole, the results demonstrated that no significant difficulty was experienced by either group. 


\section{Conclusions}

In this paper an attempt has been made to show the potential of font and colour in terms of textual presentation, and to demonstrate that they do not perform a merely technical role; on the contrary, they have the capacity to convey meaning and to have semantic significance. The examples which have been presented make it possible to assert that manipulations of colour and font in tandem can perform complementary functions. The context and the distribution which of the two is the dominant attribute in any particular instance. The examples given show that when font and colour are used together in this manner, a single sentence can be read in two or more ways, thus making the sentence polysemantic. This being the case, new strategies are needed for reading texts in which these font-related and colourrelated techniques are employed. it can be context-related and context-dependent. The examples also show the possibility of the texts embodying an element of emotional colouring, and having an effect which might be termed 'font and colour play'.

As described in the previous section, an experiment was conducted to gain insights into the comprehension of messages by a selected group of individuals, and the results made it possible to conclude that grasping the meaning of the material presented which involved a mixture of verbal, paraverbal and non-verbal means did not present significant difficulty for either the male or the female participants in the survey, although some slight differences between the two sexes was tabulated. On the whole, females required somewhat more time to comprehend the message than males. A significant number of females perceived all the different means (verbal, paraverbal and non-verbal) as a single entity. However, on the whole it was manifested that members of both sexes were basically able to grasp and retain the content of what they read.

A primary reason for conducting this survey was to provide balance for our study as a whole, in the sense that we devoted extensive attention to the techniques utilized by the creators of multimodal texts in which tactics of font and colour manipulation were utilized, but a study of those aspects, and the various refinements of multimodal techniques which they displayed, would have been incomplete without a corresponding inquiry into the actual response that was evoked in a sample group of recipients exposed to material of the type which is the focus of our attention.

\section{References}

Bateman, J. (2014). Text and Image: a Critical Introduction to the Visual/Verbal Divide. London; New York: Routledge.

Bateman, J. A., Wildfeuer, J., \& Hiippala, T. (2017). Multimodality: Foundations, Research and Analysis - A Problem-Oriented Introduction. Berlin: De Gruyter.

Bergström, B. (2008). Essentials of Visual Communication. Laurence King Publishing Ltd.

Jewitt, C. (2014). The Routledge Handbook of Multimodal Analysis. Abingdon, Oxon; Milton Park, Oxfordshire: Routledge.

Kress, G. and van Leeuwen, T. (1996). Reading Images: The Grammar of Visual Design. London: Routledge. 
Lester, P. M. (2006). Visual Communication Images with Messages. Belmont, CA: Wadsworth Publishing Company.

Lester, P. M. Syntactic Theory of Visual Communication. California State University, Fullerton CA. Retrieved from http://paulmartinlester.info/writings/viscomtheory.html

Makaruk, L. (2018). Paralinhvistychni zasoby yak mekhanizmy vplyvu i manipuliatsii u suchasnomu anhlomovnomu multymodalnomu reklamnomu dyskursi [Paralinguistic devices as mechanisms of influence and manipulation in modern English multimodal advertising discourse]. Psycholinguistics, 23(2), 148-164. https://doi.org/10.5281/zenodo.1208625

Mealing, S. (2000). Do You See What I'm Saying? In: M. Yazdani, P. Barker, (Eds.). Iconic Communication, (pp. 68-79). Bristol, UK and Portland, OR, USA: Intellect Books.

Nørgaard, N. (2018). Multimodal Stylistics of the Novel: More Than Words. Routledge, Taylor $\&$ Francis.

O’Halloran, K. L. (2014). Multimodal Studies: Exploring Issues and Domains (Routledge Studies in Multimodality). 1st Edition. London: Routledge.

Unsworth, L. and Cleirigh, C. (2009). Multimodality and Reading: the Construction of Meaning Through Image-Text Interaction. In: C. Jewitt, (ed.). The Routledge Handbook of Multimodal Research, (pp. 151-163). London; New York: Routledge.

\section{Sources}

Ads for Rhetorical Analysis. (2017). Retrieved from https://www.pinterest.ru/pin/241646336231948692/

Blog Anubis. (2017). Retrieved from http://bloganubis.com/2008/07/29/beat-cancer/

Ireland's first 'coughing billboard' highlights the risk of lung cancer. (2018). Retrieved from https://www.irishmirror.ie/news/irish-news/irelands-first-coughingbillboard-highlights$\underline{11492605}$

Pinoy Listing. (2018). Retrieved from http://www.pinoylisting.com/publishingadvertising/di9it_i9012

Pinterest. (2016). Retrieved from https://www.behance.net/gallery/863280/AmericanEagleSpring-2005-Magazine-Advertising

Pinterest. (2017). Retrieved from https://www.pinterest.com/babygirl17_/drinking-and-drivingposters/?lp=true

Pinterest. (2018). Retrieved from https://www.pinterest.co.uk/pin/328340629075795785/?1p=true

Pinterest. (2018). Retrieved from https://www.weightwatchers.com/us/

River View Observer. 2016. No. 6. Vol. XX.

Senor Snacks. (2017). Retrieved from http://www.senorsnacks.be/partners.html 